$1-1-1955$

\title{
A mobile circular sawmill for farm woodlots in West Virginia
}

Jack B. Byers

Follow this and additional works at: https://researchrepository.wvu.edu/ wv_agricultural_and_forestry_experiment_station_bulletins

\section{Digital Commons Citation}

Byers, Jack B., "A mobile circular sawmill for farm woodlots in West Virginia" (1955). West Virginia Agricultural and Forestry Experiment Station Bulletins. 377.

https://researchrepository.wvu.edu/wv_agricultural_and_forestry_experiment_station_bulletins/370 @ WVU. It has been accepted for inclusion in West Virginia Agricultural and Forestry Experiment Station Bulletins by an authorized administrator of The Research Repository @WVU. For more information, please contact ian.harmon@mail.wvu.edu. 
West Virginia University Libraries 



\section{A \\ Mobile Circular Sawmill For Farm Woodlots in West Virginia}

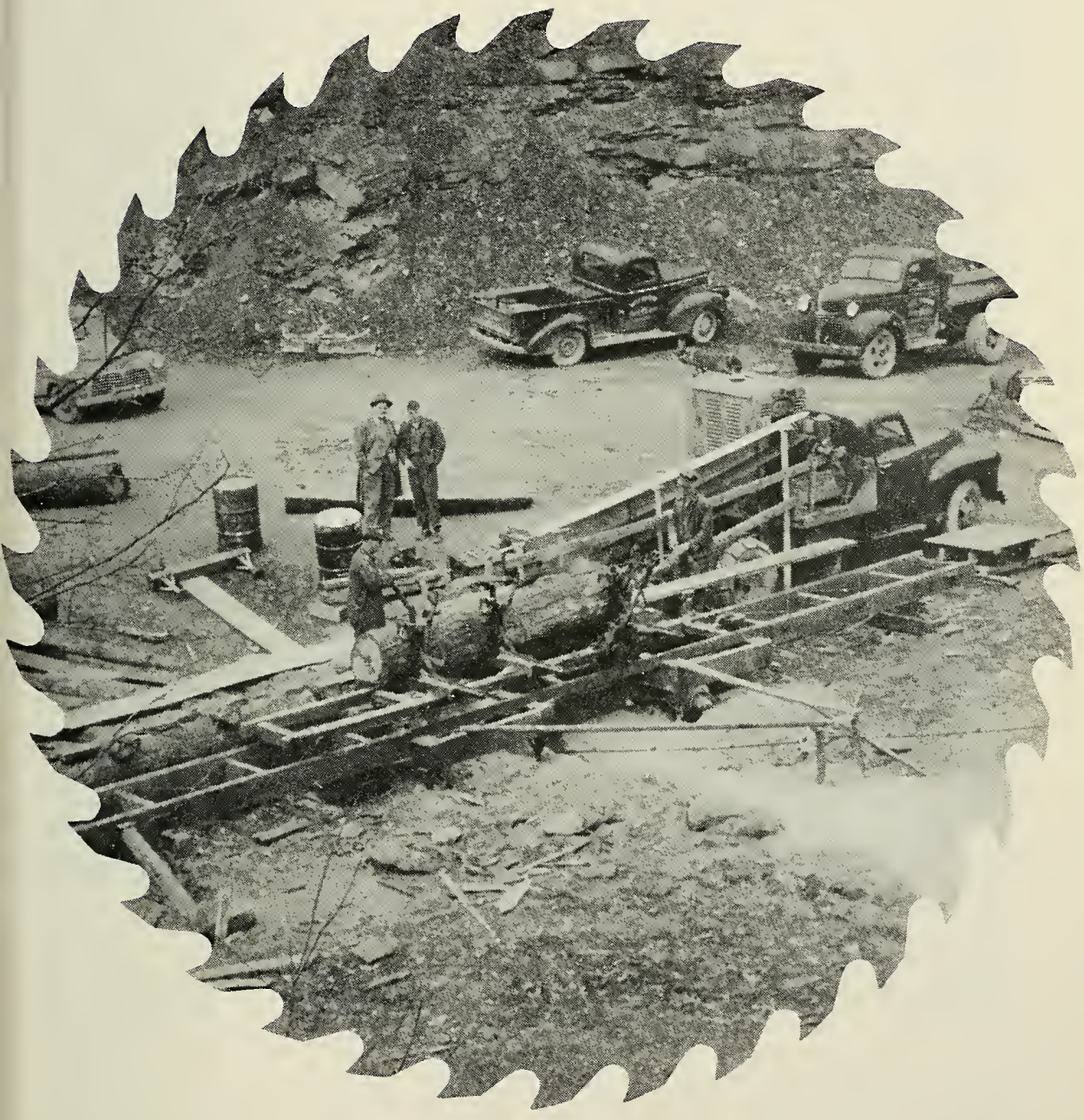

Bulletin 377

June 1955

WEST VIRGINIA UNIVERSITY AGRICULTURAL EXPERIMENT STATION 


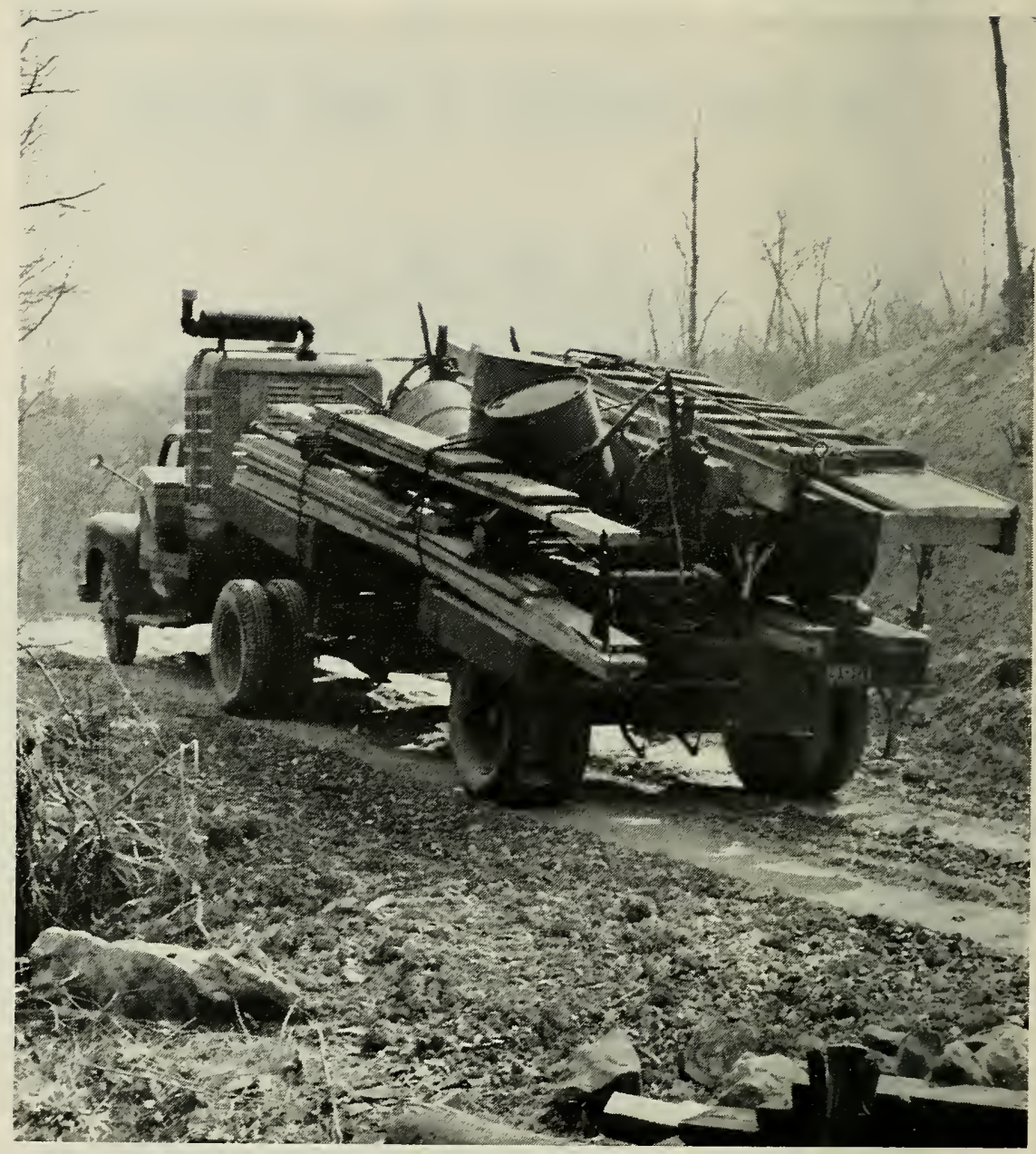

THE MOBILE SAWMILL rigged for moving, without the gooseneck in place. Although the gooseneck permitted greater speeds when traveling on improved highways, it was seldom used during the course of the sawmill's operations. Without the attachment the unit had a higher road clearance and a shorter turning radius, thus permitting greater maneuverability in rough country. 


\section{CONCLUSIONS}

(1). Mechanical operation of the mobile sawmill unit was satisfactory, but it could be improved by modifications and additional accessories, principally in the addition of accessories to improve efficiency in setting up, moving, and dismantling.

(2). The quality of lumber produced was satisfactory.

(3). The mobile unit can be assembled at a cost which would not be excessive, provided enough work is available to keep it in fairly constant operation.

(4). Operating costs rise sharply for sets of less than 20,000 board feet, but the distance traveled from set to set is a significant consideration in determining the marginal operation.

(5). The availability of jobs for the unit is the factor which will limit its use more than any other. Without substantiating data, it has been concluded by those who worked on the project that one man could not afford to operate a single mill of this type in custom sawing as a private enterprise unless his operations were scheduled ahead, either by another person or agency, or by heavy demand for his services in order that he could work on the mill crew. With fairly heavy demand for services, one man could probably make a profitable operation from supervision of two or three mobile sawmill units without working as a member of the crew.

(6). The mobile unit offers particular promise in circumstances such as those listed below:

a. Operation by an agricultural cooperative for the primary benefit of members, where a large part of the administrative functions could be handled by officers of the cooperative.

b. Operation by a lumber company which hauls logs long distances to a permanent sawmill, as a subsidiary mill to saw mine materials and other low-grade products from the smaller and lower-grade logs at the logging site.

c. Operation by a mine company for sawing mine material from its own property where available volumes per acre would necessitate frequent moves from one set to another.

d. Operation by a wood products company specializing in lumber of certain valuable species, such as black locust, ash, holly, or other species which are found in limited quantities, where the individual operation would be small. 


\section{ACKNOWLEDGMENT}

The author is indebted to Raymond S. Lockwood, who assembled the mobile sawmill, supervised the test operations, and managed the unit in operation from October, 1948, to August, 1950. He is also indebted to the following: Dr. W. C. Percival, Forester, West Virginia University Agricultural Experiment Station, for handling much of the administrative work in connection with the project; C. E. Trembly, Treasurer, West Virginia Forest Products Association, for his help in assembling cost data; the members of the State Soil Conservation Committee for providing the principal items of equipment used to assemble the unit, and especially E. D. Knight, chairman of the Machinery Subcommittee, for his interest and active support; A. F. Millender, Soil Conservationist, and the members of the Board of Supervisors of the West Fork Soil Conservation District for providing a test area for the unit, scheduling operations, and making their records available; R. O. Gustafson, Associate Forester, West Virginia University Agricultural Experiment Station, for his advice and assistance in certain phases of the mill's operation; Donald G. Hebb, manager of the unit in operation from April to November of 1951; Ray C. Call of the Ray C. Call Company of Steubenville, Ohio, and the Reliance Trailer Manufacturing Company of Steubenville, Ohio, for assistance in the design of the transport unit; Dr. A. D. Longhouse, Agricultural Engineer of the West Virginia University Agricultural Experiment Station, for cooperating in the design and fabrication of experimental parts of the unit.

WEST Virginia UNIVERSITY

Agricultural Experiment Station

College of Agriculture, Forestry, and Home Economics

H. R. Varney, Director

MORGANTOWN 


\section{A Mobile Circular Sawmill for Farm Woodlots in West Virginia}

\section{INTRODUCTION}

Jack B. Byers*

Background

URING the period between World War I and World War II, a marked change occurred in West Virginia's flourishing lumber industry. The timberman no longer found vast primitive forests to challenge his axe. The last of the mammoth spruce and hemlock had been removed from Canaan Mountain, the rafts of prime yellowpoplar logs were no longer a familiar sight on the Guyan River, and the prized virgin red oak had disappeared from the Cheat River valley.

The land had become divided into small ownerships. Towns, farms, mines, and factories dotted the countryside where the original timber had been removed. Second-growth timber which came in on the cutover land was examined more closely by the timberman, who gradually came to depend upon it for his principal source of supply.

While this change was taking place the number of small portable sawmills gradually increased. With few exceptions, they were circular mills which could neither equal the rate of production nor the quality of lumber produced by the large bandmills. They could, however, produce acceptable lumber at lower cost, which gave them an advantage in handling the smaller, scattered second-growth timber.

With typical ingenuity, loggers and sawmillers went about their business, developing equipment which was more suitable to the types of operations with which they were confronted. Sawmills and logging equipment had to be made more portable to save excessive skidding and transportation costs in bringing the logs to the log deck.

Portability as a feature of the sawmill unit became increasingly important as the era developed, but the cost of moving remained one of the critical factors which made the difference between profit and loss and prevented operators from working many small tracts. Some of these

* Jack Byers is Assistant Forester, Agricultural Experiment Station, and Assistant Professor of Forestry, College of Agriculture, Forestry, and Home Economics. 
tracts could only be operated by hauling the logs to a mill some distance away. Often a farmer in need of a small quantity of lumber for his own use could buy it from a mill cheaper than he could cut his own timber, haul the logs to a mill, pay a custom sawing fee, and haul the lumber back to his farm.

\section{The Development of Mobile Sawmills}

American soldiers in France during World War I were impressed by types of mills mounted on horse-drawn wagons. Generally these were small bandmills which were designed more for rapid transport than for rapid sawing. Features of the mills which did not appeal to the Americans were the hand-feed systems, which could be used in Europe because of the availability of cheap labor, and the thin-gauge spring set bandsaw blade which the French preferred. However, the mobility built into some of these units stirred the imagination of the men who worked with them (1).

From that time, Americans began experimenting with skids and wheels under their small mills. Several lumber companies, principally in the South, claimed some success. One company not only operated a wagon-mounted circular mill, but successfully operated a 48-inch bandmill mounted on wheels for several years prior to 1939 (2). Generally, the novelty met with little success and was not accepted as a practical modification except under certain restricted conditions of operation.

Before the Second World War began, at least one mobile circular mill had appeared on the market and met with some success in sawing softwoods and small hardwoods $(3,4)$. By the end of the war, the idea had spread to the Northwest, where a heavier model, suitable for relogging and salvage operations, was being produced $(5,6)$. From time to time during the early post-war years other lumbermen and sawmill manufacturers embodied their own ideas into new models, with varying degrees of success.

\section{Prospects for Use on West Virginia Farms}

Just before the beginning of the Second World War, a concerted effort was started to develop an adequate farm forestry program in West Virginia. Action was initiated almost simultaneously by a number of Federal, State, and private agencies.

One of the earliest conclusions of the men who participated in this work was that good forestry practices would be adopted by farmers only to the extent that their woodlands could be brought into the farm economy and be made to contribute toward the farm income on a basis similar to that of their agricultural crops. The extent to which this 
could be done depended on the value the farmer could realize from his woodland products, and how frequently he could receive the returns.

To a greater extent than for any other class of forest land, farm woodlots under managenent require very portable, or mobile equipment for logging and sawmilling operations. The average West Virginia farm contains about 47 acres of woodland (7), but the total area of farm woodland represents almost one-fifth of the total area of the State. The small size of most farm woodlots presents a problem to the operator, who can afford to move his logging and sawmilling equipment to a new set only when assured of a sufficient volume of timber to pay him the cost of moving as well as the cost of current production and a reasonable profit.

The cost of moving a sawmill to a new site varies widely. It depends upon the type and condition of equipment, mode of transportation, distance, condition of roads, efficiency of the crew, and the time of year during which the sawing operation will be carried on. The latter factor often determines the type of superstructure to be erected over the sawmill. In a general way, the smaller the volume to be sawed on a set, the higher the cost per thousand board feet which must be charged against the sawing for moving the mill onto the set. This simple principle works to the disadvantage of most farmers because of the small size of their woodlots. Farmers with available sawlog volumes up to 50,000 board feet have had the most difficulty in arranging for logging and sawing operations.

It was to meet the need of this class of farmers that the West Virginia University Agricultural Experiment Station undertook in 1946 to design a mobile sawmill unit which would reduce the cost of moving from set to set, and which would suit the particular set of conditions found in the State's mountainous hardwood region.

This bulletin is the culmination of the project which resulted in the construction and operation over a period of four years of such a mobile sawmill unit.

\section{PROCEDURE}

\section{Administrative Organization}

Four agencies cooperated in the execution of the project. They were the Agricultural Experiment Station of West Virginia University, the West Virginia Forest Products Association, the State Soil Conservation Committee, and the West Fork Soil Conservation District. The part of each agency in the construction and operation of the sawmill unit and analysis of data is outlined below. 
The Agricultural Experiment Station-The Experiment Stacion initiated the project, designed and constructed the mobile sawmill unit, supplied certain experimental parts, operated the mill for four months on a trial basis before putting it into regular service, assisted in supervision of its operation after it was placed in service, assembled and analyzed cost and production data, made experimental structural modifications from time to time, and coordinated the work of the cooperating agencies.

The West Virginia Forest Products Association-The Association, a forest land owners cooperative management and marketing association, was in direct charge of the management of the mill, including the financing of operations, the employment of operating personnel, and the maintenance of equipment. The Association handled payrolls, taxes, and insurance on employees, direct operating costs, and repairs costing not more than $\$ 25.00$, which were classed as minor repairs.

The State Soll Conservation Committee-The committee made available most of the equipment needed to assemble the unit, including the standard portable sawmill, the power plant, the truck-tractor, the semi-trailer, and other tools and accessories.

The West Fork Soll Conservation District-The district, with headquarters at Clarksburg, West Virginia, accepted the sawmill unit on loan from the State Soil Conservation Committee under an agreement similar to that by which other heavy equipment is placed in service in the several districts. The district assumed responsibilty for scheduling operations on farm woodlots of the district's cooperators and also accepted responsibility for certain financial functions, including the collection of fees for sawing, payment to the Association of a certain percentage of the fees to cover its expenses, payment of insurance and licenses on the equipment, maintenance of a sinking fund which would permit the eventual repayment of the original cost of the equipment to the State committee, and payment for repairs costing in excess of $\$ 25.00$, classed as major repairs.

\section{Design and Construction"}

The following objectives were set up as minimum requirements for a mobile sawmill unit suitable for sawing small volumes from woodlots located in the mountainous hardwood region:

1. The unit must be capable of being dismantled, moved, and set up rapidly to keep moving costs low.

\footnotetext{
*Prints showing construction details may be obtained from the Agricultural Experiment Station, West Virginia University, Morgantown, West Virginia.
} 
2. It should be capable of maneuvering over narrow, poor mountain roads and to sone extent off the road to permit it to move in close to the timber.

3. It should be capable of producing quality lumber at least equal to that of a good portable sawmill.

4. The cost of construction should be reasonable so that the mill may be duplicated by sawmill operators.

To meet these four objectives, the eventual design consisted of a standard-type small portable sawmill which was modified and adapted to a semi-trailer. The trailer was coupled to a truck-tractor with a standard fifth-wheel semi-trailer coupling, and the power unit was mounted on the truck-tractor, between the cab and the fifth wheel, remaining there during operation and transit. Edging was done on the headsaw, and the lumber was not end-trimmed.

The basic equipment consisted of a Frick \#00 belt feed sawmill with 15-foot carriage and 45 feet of ways, a specially constructed semitrailer with removable gooseneck, a General Motors Diesel engine rated at 87 brake horsepower, and a Chevrolet 2-ton truck with a 161-inch wheelbase.

The husk and center section of ways were permanently mounted on the semi-trailer over heavy oak sills, and a sawyers platform was built on. An offbearer's platform and dead rolls were installed, but could be removed when the unit was dismantled for transit. The end sections of ways were rebuilt from heavier stock than supplied by the manufacturer and were reduced in length from 15 feet each to 12 feet. A suitable coupling mechanism for attaching the end sections of ways to the center section was designed and made. The fced pulleys were relocated from the end sections of the ways to the center section in order that no changing of the fecdworks, particularly the cable, would be necessary when the mill was dismantled for moving to a new set.

Probably the most critical problem in the design was that of providing a solid foundation which would be capable of quick adjustment and easy operation, and yet would give adequate support to the mill in operation with no external bracing for stabilization. This was solved by using 12 specially constructed sill-type jacks, made with a much higher capacity than would be required for the support of the dead weight alone. Eight of the jacks were mounted on the center, or trailer section of the mill and two were mounted near the end of each of the end sections. The jack and sill assembly on the end sections of ways is shown in Figure 1.

A fundamental question which confronted the designers was whether steel construction should be used throughout, or whether wood should 


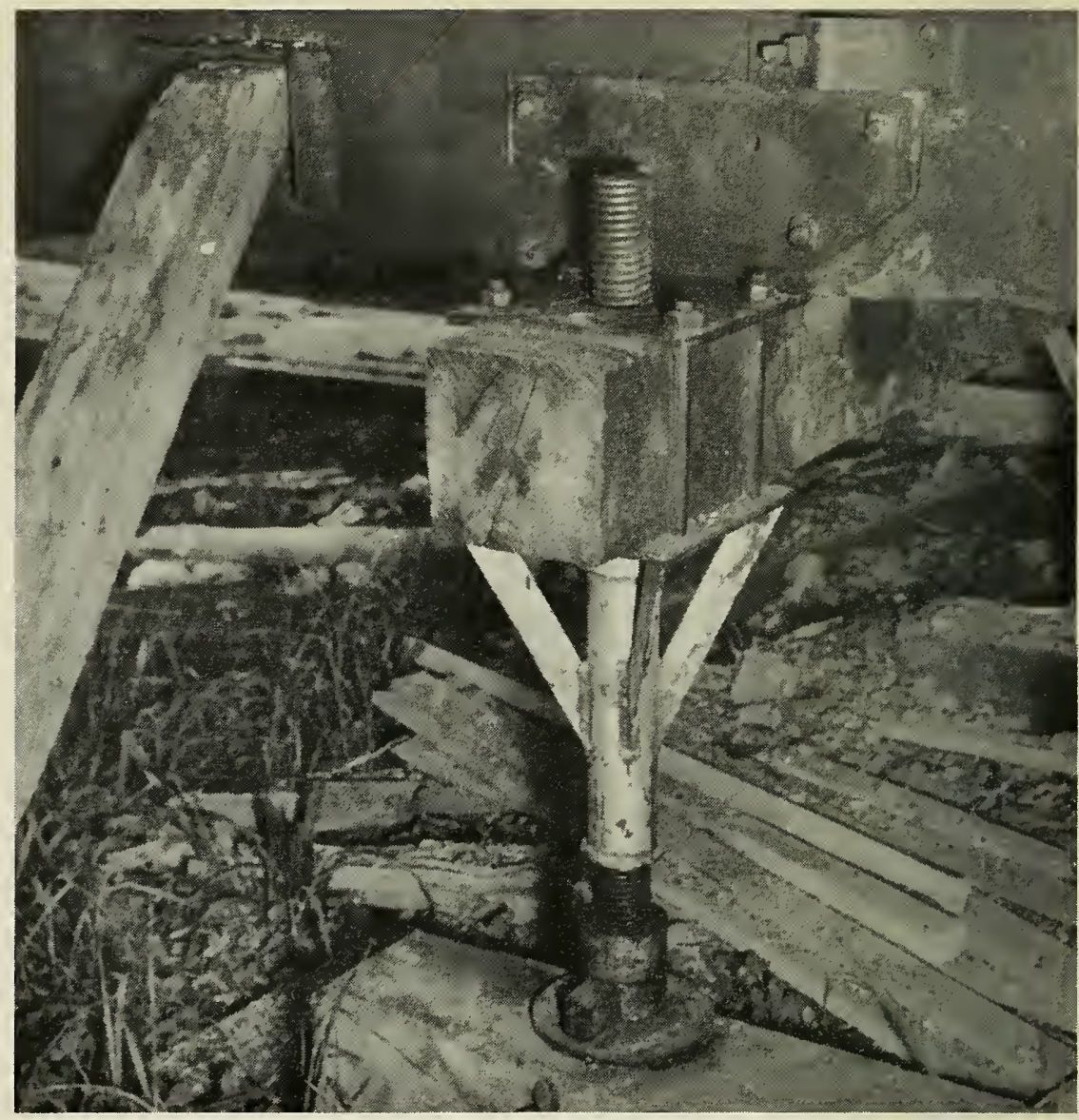

FIGURE 1. JACK AND SILL assembly on the end sections of ways. The skewback at the upper right holds a sway brace in the ways. The ways may be straightened by adjusting the tension on the pairs of crossing sway braces. At the left is the wooden brace used to improve stability of the ways when loading and turning large logs.

be used where possible. The decision was in favor of wood, for the following reasons:

1. It is less expensive and more commonly available to sawmillers who might be interested in duplicating the unit.

2. It is more easily replaced if damaged.

3. It is more resilient and absorbs vibration better than steel.

Clear white pine was used to rebuild the end sections of ways. It was necessary that the end sections, which would be placed in position by hand, be as light in weight as possible and yet offer the greatest possible strength and stability for their weight. White pine was selected 
because it was the best material available at the time. Red oak was used for the sills.

Special machining of metal parts was necessary only in two cases. The 12 sill jacks were specially made, as were the two way connector units.

The unit was assembled by one man, with part-time help, in about two months. The time does not include construction of the trailer. Machining, bending of plate stock, cutting of heavy stock, and welding of metal parts were done in local machine shops and garages. Drilling, threading, cutting of light stock, and forging of metal parts were done by the assemblers, as was all woodworking, using ordinary hand tools and an electric drill press.

The mill has a maximum headsaw diameter limit of 58 inches. Sizes used in operation were 54-inch and 56-inch. Maximum headblock opening is 32 inches. With a 15-foot carriage traveling on 39 feet on ways, it is possible to handle logs up to 18 feet long. At one time a 22-foot log was put through the mill by overrunning the ways. The diameter of $\log$ the mill will handle depends only upon the size which the headsaw can break down or the size which can be handled on the deck and carriage. At one time a 10 -foot $\log$ scaling 640 board feet was successfully sawed, although the first slabs had to be cut loose with an axe.

When very large logs were sawed, a diagonal prop was installed between the ways and the ground on the side opposite the log deck, which helped to absorb lateral shock, and temporary props were placed under the ways adjacent to the headsaw.

In dismantling the unit, the carriage is centered over the trailer and chained in place. The offbearer's platform and dead rolls and the two 12-foot end sections of ways are detached and loaded on the trailer over the carriage and husk. Other paraphernalia, including the sawdust drag, cribbing, fuel cans, and hand tools are also loacled, and the load is chained and boomed to hold it in place. The front of the trailer is then jacked up, the truck backed under to engage the fifth wheel, and the unit is ready to move.

Setting up is the reverse of this procedure. The trailer is pulled into place adjacent to the log deck, the truck is detached, and the front end of the trailer is lowered with screw jacks. The accessories are unloaded, and the trailer is leveled by use of the sill jacks which rest on mud sills on the ground. The end sections of ways are attached and leveled, and the other parts of the mill are attached. The truck is pulled into position and leveled, and the belt from the power unit is placed around the mandrel pulley.

Two features of the original design were tried and discarded. The first was a detachable gooseneck on the trailer as shown in Figure 2. 


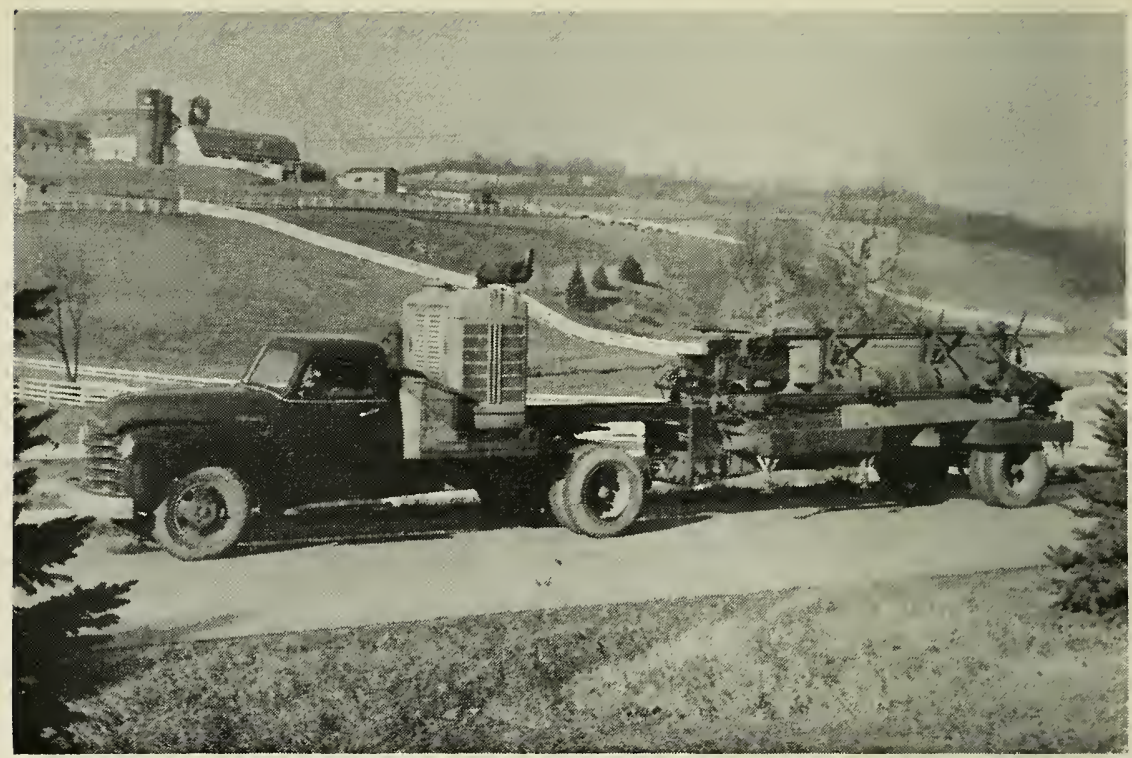

FIGURE 2. GOOSENECK for the front of the trailer is shown in use. Although the gooseneck would have solved the problem of raising and lowering the front of the trailer in dismantling and setting up the mill, it was too heavy to be handled by the number of men usually available and was seldom used. The gooseneck improved the roadability of the unit somewhat on good roads, but was a handicap on poor roads because it increased over-all length of the unit.

This feature was intended to improve roadability of the unit when traveling considerable distances on good roads. Its use extended the over-all length of the unit in transit by about six feet, which made travel more difficult on narrow roads. The principal reason for discarding it was because of its considerable weight and the amount of time necessary to detach it and mount it when setting up and dismantling the mill. The gooseneck, when in place, interfered with mounting of one end section of the ways and had to be cletached before the mill was assembled. It was found that although the nill rode at an awkward-looking angle when the front of the trailer itself was raised over the fifth wheel, the trailer rode well in that position and the reduction in over-all length was a decided advantage.

The second feature discarcled was the landing gear, which was intended to raise and lower the front of the trailer. The one used on this unit was adapted from a standard semi-trailer landing gear. It was discarded because: (1) It protruded too far under the trailer so that it was usually necessary to dig holes for the mud shoes in order to level the mill, especally when setting up on a hillside; and (2) the gear ratio was not high enough to lift the front of the trailer to the height necessary to engage the fifth wheel without considerable strain, which eventually 
resulted in its becoming damaged beyond use. A landing gear which would rececle into the framework of the trailer when not in use and which had the strength to raise the trailer as high as necessary would be a definite advantage in this sort of unit.

\section{General Specifications}

\section{In Sawing}

Maximum size headsaw -58 inches

Maximum headblock opening-32 inches

Length of ways-39 feet

Length of carriage-15 feet

Headblocks-three, with taper attachments

\section{In Transit}

Over-all length with gooseneck-38 feet

Over-all length without gooseneck-32 feet

Gross weight loaded with all paraphernalia-21,500 pounds

Over-all width with mandrel mounted -8 feet $71 / 4$ inches*

Over-all width with mandrel dismounted-8 feet.

\section{OPERATION \\ Organization on the Ground}

Application for the services of the mobile mill were made to the West Fork Soil Conservation District office in Clarksburg. A representative of the office ascertained the approximate volume to be sawed and other general features of the operation. This information was passed on to the mill manager, an employee of the Association. An effort was made to schedule jobs as far as possible in advance of operation to allow time for careful planning of travel distances from set to set in order that they be kept as short as possible.

The timber to be cut was usually marked by the county forester, who is a service forester employed by the State Conservation Commission.

The farmer was responsible for having the timber cut and the logs delivered to the skidway and for disposition of the lumber from the dead pile at the end of the offbearer rolls.

The sawmill manager usually made one visit to the farm before moving the mill in, to check the quality of logs and other conditions of operation and to designate the site the mill would occupy in order that the farmer would know where to skid the logs.

*This width exceeds maximum road width for vehicles in West Virginia. Movement over State highways may be made only with prior permission of the State Road Commission. 
The sawmill crew took charge of the logs on the log deck, sawed them into lumber or timbers according to a saw-bill furnished by the farmer, and deadpiled the lumber at the end of the offbearer rolls.

Figure 3 shows a typical set for sawing a small volume of lumber.

During the first year of operation, the Association used a sawmill crew composed of a sawyer and offbearer and part-time dogger. The dogger was added to the crew during the course of the year to ease the burden on the sawyer, helping to load and turn logs and set dogs. A spot check indicated that the addition of the third man to the crew did not significantly change the costs per thousand board feet sawed. The resulting increase in production only compensated for the extra labor expense of employing the third man.

\section{General Considerations}

No adequate control study was feasible because of the wide variation in conditions of operation of sawmills and because of the large expense such a project would entail. No reason has been found to indicate that the actual sawing costs of the mobile sawmill, or those costs exclusive of moving, dismantling, and setting up, are not comparable with the sawing costs of a similar type of portable mill operated

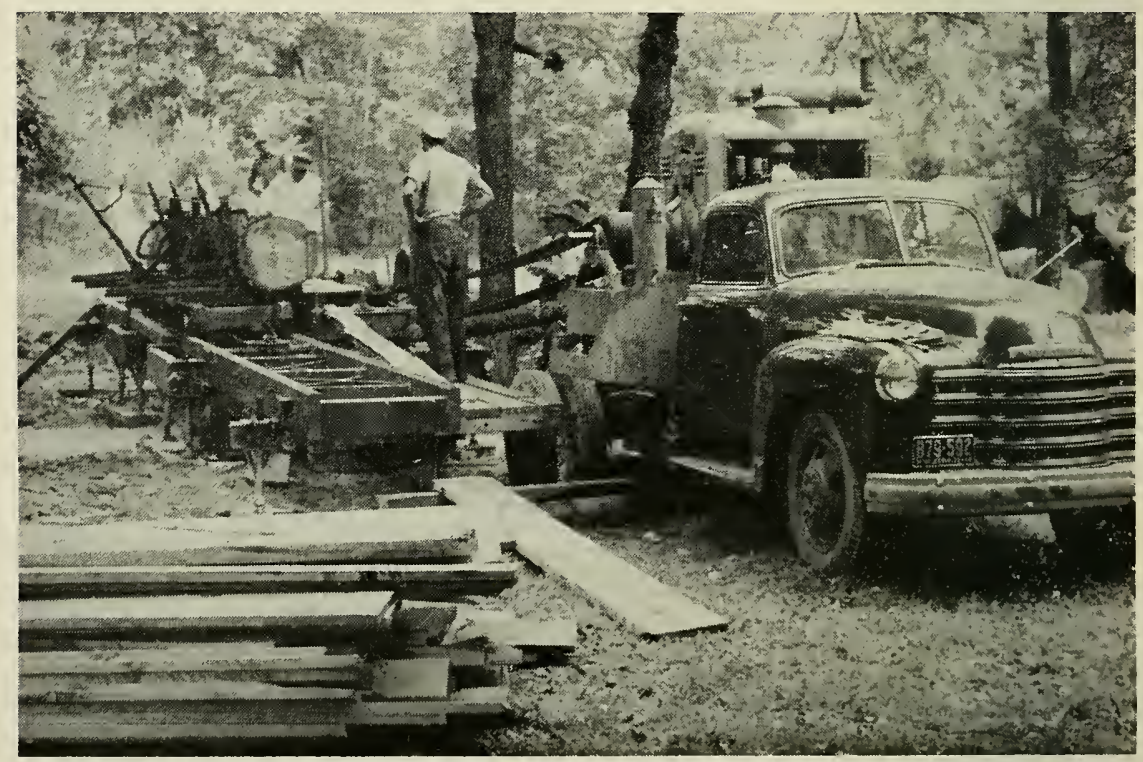

FIGURE 3. THE MOBILE SAWMILL in operation on a small set. Offbearer rolls and belt guard are not installed in this picture. On small sets the wheels were not removed from the trailer, and sometimes the sawdust conveyor was not installed. 
with similar crew, equipment, facilities, and under similar conditions. The two principle items of expense which would be expected to vary between the mobile mill and a comparable type of portable mill are the initial cost and moving costs.

Although not a part of this study, the mobile character of this sawmill should account for considerable savings over the skidding and $\log$ hauling costs of a portable or permanent sarmill operation.

It should be recognized in interpreting data from the testing of equipment of this sort that results are inevitably associated with the capability and industry of the men who operate the equipment. In the case of the sawmill, the sawyer is of prime importance. During the 12month period for which basic cost data is reported here, three sawyers operated the mill at various times. An arbitrary classification of their abilities would be one good, one fair, and one poor.

Several other characteristics of this type of sawmill, and of the area in which it operated should be noted:

(1). The sawmill operated within a 30 -mile radius of Clarksburg, West Virginia. The mill crew lived in the vicinity of Clarksburg and commuted daily from their homes to the mill. This traveling was unpopular with the men and resulted in frequent turnover of operating personnel. In addition, it was necessary to pay higher wages than would otherwise have been necessary in order to compensate the men for the extra travel.

(2). Since the mill was employed exclusively in custom sawing, the quality of lags sawed was generally inferior to that which a portable mill would saw. The sawmiller who purchases stumpage or logs with a view to selling the sawed products is selective in the species and quality of logs he will purchase, depending on market demands and prices. The simplicity of operation of the mobile sawmill, from the standpoint of the farmer, was an invitation to bring in any $\log$ which would produce any piece of lumber for which some eventual use on the farm could be foreseen. A considerable number of operations were conducted on areas which were being cleared for strip mines or agricultural use, where the logs were small and with a high percentage of inferior species.

On some operations hickory was the predominant species sawed and accounted for a considerable reduction in production. Butt cuts of fence-row trees were not sawed, but large original-growth logs frequently did appear and were sawed even though the cost of sawing on the light mill without benefit of $\log$ loader or turner far exceeded the value of the lumber produced. In one case the farmer requested that his entire lumber production be sawed into roosts for turkey pens, and this was done, although at a considerable sacrifice to the rate of production. 
(3). In sawing small sets, with frequent moves, considerable difficulty was met by administrative personnel in keeping jobs lined up ahead of the mill. The unit was not moved onto a set until a reasonable number of logs were at the skidway and reasonable assurance was given that the mill would be kept well stocked. In spite of the best efforts to keep the unit in constant operation, some time was lost due to inadequate supply of logs on the landing or because operations could not be scheduled far enough in advance. It was particularly difficult to schedule operations during the planting and harvest seasons. Farmers could best afford the time to produce logs for the mill cluring the winter. However, the unit found the greatest difficulty in operating during this season. To help overcome this situation, an effort was made to schedule the smaller sets during the summer and fall and to operate the larger sets during the winter and spring when the problem of transport was the greater.

(4). The basic feature of the unit was mobility, which necessitated compactness in order that the mill could move as a completely self-contained unit from set to set in a single trip. It did not, therefore, contain a number of accessories often used with comparable portable mills, such as an edger, cut-off saw or trimmer, or a $\log$ turner. Lack of an edger and $\log$ turner was responsible for holding production down, but lack of a cut-off saw or trimmer was not of particular concern to the farmers for whom the sawing was done. End-trimming would have increased the cost without a corresponding increase in the rate of production, and the lumber was generally destined for use on the farm, where end-trimming would be an unnecessary refinement. All of the lumber was edged on the headsaw, a practice commonly used on smail mills not equipped with edgers.

\section{COST AND PRODUCTION DATA Initial Cost and Production}

The initial cost of the mobile sawmill and transport equipment is shown in Table 1. All equipment was purchased new except the original fifth-wheel semi-trailer coupling.

Initial costs were divided into costs which were applicable to (I) the sawmill unit, or that part which was used directly for the sawing of lumber; and (2) the transport unit, or that part which was used primarily for moving the mill from set to set. The division was made in order that depreciation expense could be applied separately for sawing and transport in calculating total costs of the two operations separately. 


\begin{tabular}{|c|c|c|c|}
\hline EQUIPMENT & $\begin{array}{l}\text { SAWMILL } \\
\text { UNIT }\end{array}$ & $\begin{array}{l}\text { I RANSPORT } \\
\text { UNIT }\end{array}$ & TOTAL \\
\hline \multirow{2}{*}{\multicolumn{4}{|c|}{$\begin{array}{l}\text { Sawmill } \\
\text { Basic mill, with extra saw and chain }\end{array}$}} \\
\hline & \multirow{2}{*}{$\begin{array}{r}\$ 1518.65 \\
286.00\end{array}$} & & $\$ 1518.65$ \\
\hline Screw type sill jacks (12) & & & 286.00 \\
\hline $\begin{array}{l}\text { Materials (timbers, metal stock, bolts, } \\
\text { nails, etc.) }\end{array}$ & \multirow{3}{*}{$\begin{array}{r}150.16 \\
44.70 \\
550.00\end{array}$} & & 150.16 \\
\hline Services (welding, cutting, etc.) & & & 44.70 \\
\hline Labor & & & $\begin{array}{r}550.00 \\
2549.51\end{array}$ \\
\hline $\begin{array}{l}\text { Trailer, with detachable gooseneck, dual wheels, } \\
\text { and air brakes }\end{array}$ & 490.00 & 490.00 & 980.00 \\
\hline $\begin{array}{l}\text { Truck-tractor, } 2 \text { ton, with power unit mounting, } \\
\text { and fifth wheel coupling }\end{array}$ & \multirow{2}{*}{$\begin{array}{r}250.00 \\
3422.00\end{array}$} & \multirow[t]{2}{*}{1837.53} & \multirow{2}{*}{$\begin{array}{l}2087.53 \\
3+22.00\end{array}$} \\
\hline Diesel engine, 87 hp. & & & \\
\hline $\begin{array}{l}\text { Accessories (hand tools, fire extinguisher, } \\
\text { first aid kit, etc.) }\end{array}$ & 157.62 & 26.00 & 183.62 \\
\hline Total Cost ............................... & $\$ 6869.13$ & $\$ 2353.53$ & $\$ 9222.66$ \\
\hline
\end{tabular}

The trailer was used as an integral part of the sawmill during sawing operations, serving as a solid substructure and base of support for the entire mill, and facilitated setting up and dismantling operations; in transit it carried the mill and all of its equipment except the power plant. Both operations, therefore, should be charged with a part of its cost. Equal value was assigned to each of the operations, for although the trailer was used for a longer period of time as a support in sawing, some of the more expensive parts of the trailer (the axle, wheels, tires, fifthwheel plate and pin) served a purpose only in transport of the mill.

A division of costs was also necessary for the truck-tractor, which supported the power plant during sawing operations and furnished the power for transporting the sawmill in moving from set to set. The breakdown was made on the basis that the truck-tractor could be replaced in its service as a support for the power plant by a separate fabricated stand or trailer which would cost an estimated $\$ 250$, and therefore it served a function of that value in the sawing operation. The remainder of the initial cost of the vehicle was applied to the cost of the transport unit.

The division of costs for acccessories was made on the basis of actual use of the items purchased. The only accessory purchased primarily for the benefit of the transport unit was a set of tire chains.

The estimate of depreciation, shown in Table 2, was figured for the component parts of the mill because it permitted a more accurate estimate. 


\begin{tabular}{|c|c|c|c|c|}
\hline \multirow[b]{2}{*}{ EQUIPMENT } & \multirow{2}{*}{$\begin{array}{c}\text { INITIAL } \\
\text { Cost }\end{array}$} & \multicolumn{2}{|c|}{ ANNuAL DEPrectation } & \multirow{2}{*}{ Basis } \\
\hline & & $\begin{array}{c}\text { MOBILE } \\
\text { SAWMILL }\end{array}$ & $\begin{array}{l}\text { TRANSPORT } \\
\text { EQUIPMENT }\end{array}$ & \\
\hline Sawmill ........ & $\$ 2549.51$ & $\$ 369.90$ & $\$ —$ & Period- 5 years : residual value $\$ 700$ \\
\hline Trailer .......... & 980.00 & 44.00 & 44.00 & Period-10 years : residual value $\$ 100$ \\
\hline Truck-tractor & 2087.53 & 23.81 & 174.94 & Period-10 years : residual value $\$ 100$ \\
\hline Diesel engine & 3422.00 & 292.20 & $\underline{-}$ & Period-10 years : residual value $\$ 500$ \\
\hline Accessories .. & 183.62 & 60.00 & 3.00 & Period-Various \\
\hline Total & $\$ 9222.66$ & $\$ 789.91$ & $\$ 221.94$ & \\
\hline
\end{tabular}

Physical depreciation of the truck-tractor was high, even though actual mileage was only about 1,000 per year. In pulling the mill into position over rough woods roads, through fields, and of ten through woods of more or less open character, frequently bogging down, and standing without protection in all weather, the body and paint weathered abnormally. The mechanical condition of the vehicle apparently did not suffer as much as the body. During the first three years of operation the only repairs of any consequence were straightening of a bent tie rod, replacement of a broken valve spring, and grinding the valves.

The original fifth-wheel semi-trailer coupling, the only item which was not purchased new, and which is inclucled in Table 1 as a part of the truck-tractor, was broken and replaced. The replacement was also broken but was repaired by brazing. The excessive strain on the the fifth wheel was caused by the rough roads and terrain over which the mill traveled. Use of a universal type fifth wheel would probably have prevented the trouble.

The diesel engine was affected only by weathering and normal usage, and required no more than routine maintenance and replacment of injectors. The power plant was not shifted on the rails on which it was mounted except once when it was taken from the truck so the latter could be used for other purposes. Except for the effect of weather the power plant probably depreciated little more than if it had been used in a permanent location.

The sawmill required some constant maintenance, such as replacement of worn pawls, replacement or repair of bearing hangers, and replacement of timbers. Most of the damage could be traced directly to the sawing of larger logs than the original mill was intended to handle and to weathering. After four years of service, the white pine timbers in the end sections of ways needed to be repaired or replaced. One husk timber had been previously reinforced with steel strap under the mandrel bearing hanger. Most of the timbers would have lasted five years or 
longer. The arbitrary depreciation period of five years represents the estimated average for the life of all timbers at the rate at which the mill operated during the first four years.

\section{Production}

From October 1, 1948 to November 10, 1951, the mobile sawmill was used on 50 different operations, some of which included more than one set. The total volume sawed was $1,114,675$ board feet. Individual operations varied from 4,450 to 92,268 board feet. Thirty-four of the operations, representing 68 per cent of the total number, were of volumes less than 20,000 board feet, 12 were of volumes from 20,000 to 50,000 board feet, and four exceeded 50,000 board feet.

Organization of the sawmill crew and methods of operation varied from time to time and in some cases data for the clifferent methods could not be compared. Most of the cost data which will be presented here was gathered during the first year of operation, in which 26 operations were completed during a period of twelve months. The method of operation was fairly constant during that period and the unit was employed constantly except for small delays, most of which occurred between jobs. Production data for that period are shown in Table 3.

Table 3. Pronuction Data for One Year

Total volume sawed

Total number of operations

Average volume per operation

Average volume sawed per man-day working*

Average volume sawed per man-day sawing***
525,806 board feet

$$
26
$$

20,223 board feet

984 board feet

$\mathbf{1 , 2 6 4}$ board feet

*Includes time for setting up, sawing, dismantling and moviug.

**Includes paid sbut-down time during sawing operations.

The average production per 8-hour day of sawing time, including paid shut-down time, was about 3,500 board feet. The highest daily production recorded was 6,731 board feet of $4 / 4$ yellowpoplar lumber, sawed under favorable conditions from logs 14 to 20 inches in diameter and 12 to 16 feet long.

\section{Operation}

Operating data for the four steps in the cycle of operation, (I) moving in, (2) setting up, (3) sawing, and (4) dismantling, are shown in Table 4. Almost a full workday was required to set up, and threefourths of a workday was required for the combined process of dismantling and moving for the average operation, which required about 
Table 4. Operational Data for One Year

\begin{tabular}{|c|c|c|c|c|c|c|}
\hline OPERATION & $\begin{array}{c}\text { Actual } \\
\text { Hours }\end{array}$ & $\begin{array}{c}\text { PERCENTAGE } \\
\text { OF TOTAL } \\
\text { TIME }\end{array}$ & $\begin{array}{c}\text { Total } \\
\text { EXPENSE }\end{array}$ & $\begin{array}{l}\text { Average } \\
\text { Hours Per } \\
\text { Operation }\end{array}$ & $\begin{array}{c}\text { AVERAGE } \\
\text { EXPENSE } \\
\text { PER } \\
\text { OPERATION }\end{array}$ & $\begin{array}{c}\text { Average } \\
\text { ExPENSE } \\
\text { PER M BF } \\
\text { SAWED }\end{array}$ \\
\hline Setting Up* & 191 & 12.3 & $\$ 624.04$ & 7.35 & $\$ 24.00$ & $\$ 1.19$ \\
\hline Sawing & $1205 * *$ & 77.6 & $5,300.25$ & 46.35 & 203.86 & 10.08 \\
\hline Dismantling & 59 & 3.8 & 192.79 & 2.27 & 7.41 & .36 \\
\hline Moving ........... & $98 \dagger$ & 6.3 & 825.61 & 3.77 & $31.75 \%$ & 1.57 \\
\hline Total & 1553 & 100.0 & $\$ 6,942.69$ & 59.74 & $\$ 267.02$ & $\$ 13.20$ \\
\hline
\end{tabular}

* Includes setting up log decks.

**Includes five hours paid time lost due to breakdowns.

fIncludes 39 hours paid time lost due to breakdown and hang-up.

Average distance moved was 19.8 miles.

six days of sawing. The time required for moving and setting up could have been reduced if it had not been desirable to test the ruggedness of the unit by forcing it in close to the timber, sometimes beyond the limits of good judgment from the standpoint of economy of operation.

The time needed to set the mill up for operation varied widely. In one instance one man set the mill up without assistance in one day, whereas on another occasion it required more than two days for several men. Except for that one instance, however, whenever more than a day was required to set the mill up it was because of extraordinary difficulty in erecting a satisfactory $\log$ deck.

On one occasion, working under ideal conditions, the mill crew sawed for two hours at the beginning of the day, dismantled the unit, moved 21 miles, assembled the mill on the new set, and sawed a thousand board feet of lumber within an 8-hour work-day.

The sawing operation itself was not efficient, due more to the extreme variations in conditions of operation than to the inefficiency of the mill or mill crew. In Table 5 is shown the results of use of sawing time for nine consecutive operations. Less than 70 per cent of the time classified as sawing time was actually utilized in sawing lumber. Adjustments to the mill and filing the saw required nearly 30 per cent of the time.

Adjustments to the mill required an unusual amount of time when extremely large logs were being sawed. Filing time was unusually great in wet weather, since no $\log$ washing facilities were available, and when dense hardwoods were being sawed. On sets where there were many hickory logs it was necessary either to reduce the speed of the saw or to bunch the hickory logs and modify the set in the saw before putting them through the mill. Both of these procedures are commonly used 
Table 5. Analysis of Sawing Time and Shutdown Tine*

\begin{tabular}{|c|c|c|c|}
\hline OpERATION & $\begin{array}{l}\text { TOTAL } \\
\text { HOURS }\end{array}$ & $\begin{array}{l}\text { Average Hours } \\
\text { Per Operation }\end{array}$ & $\begin{array}{c}\text { Percentage of } \\
\text { Total Time }\end{array}$ \\
\hline Sawing …...... & \multirow{6}{*}{$\begin{array}{c}359 \\
471 / 2 \\
110^{1 / 4} \\
9 \\
41 / 2 \\
530^{1 / 4}\end{array}$} & \multirow{6}{*}{$\begin{array}{c}40 \\
51 / 4 \\
12^{1 / 4} \\
1 \\
1 / 2\end{array}$} & \multirow{2}{*}{$\begin{array}{r}67.7 \\
9.0\end{array}$} \\
\hline Adjustments & & & \\
\hline Filing saw** & & & 20.8 \\
\hline Loading and Turning Logs & & & 1.7 \\
\hline Other' & & & 0.8 \\
\hline Total & & & 100.0 \\
\hline
\end{tabular}

* Based on nine operations with total volume of 142,886 board feet.

**No log washing lacilities with mill.

$\dagger$ Rained ont, dismantling log deck to be sawed and rest stops.

on portable mills when sawing hickory logs, but the process was necessary more frequently in the mobile mill because of the small total number of logs sawed on each set. Reducing the speed of the saw was the most satisfactory procedure and resulted in less loss of time.

\section{Costs of Operation}

Costs of operation of the mobile unit are shown in Table 6 . These costs do not include the cost of management (such as arranging for the operations in advance), secretarial assistance and other office expense, liability, fire and theft insurance, social security payments other than that part which was deductible from employees' wages, workmen's compensation insurance, vehicle licenses, or interest. Only those items of expense which are indicative of performance are included.

The average cost per operation for setting up, dismantling, and moving was $\$ 63.17$, excluding the costs described in the last paragraph. With an average volume sawed per operation of 20,223 board feet, the average cost per thousand board leet for the complete moving operation was $\$ 3.12$.

The significance of volume sawed and distance traveled on the cost per thousand board feet produced is indicated by the graph, Figure 4. For example, the graph indicates that it would cost approximately the same amount per thousand board feet to saw half as nuch lumber when the travel distance was five miles as when the travel distance was 30 miles. It also indicates that to saw 20,000 board feet it cost two dollars, or 16.6 per cent more per thousand board feet when the travel distance was 30 miles than it cost when the travel distance was five miles.

Operating costs rose shaply for operations of less than 15,000 to 20,000 board feet, depending upon the distance traveled to the set. 


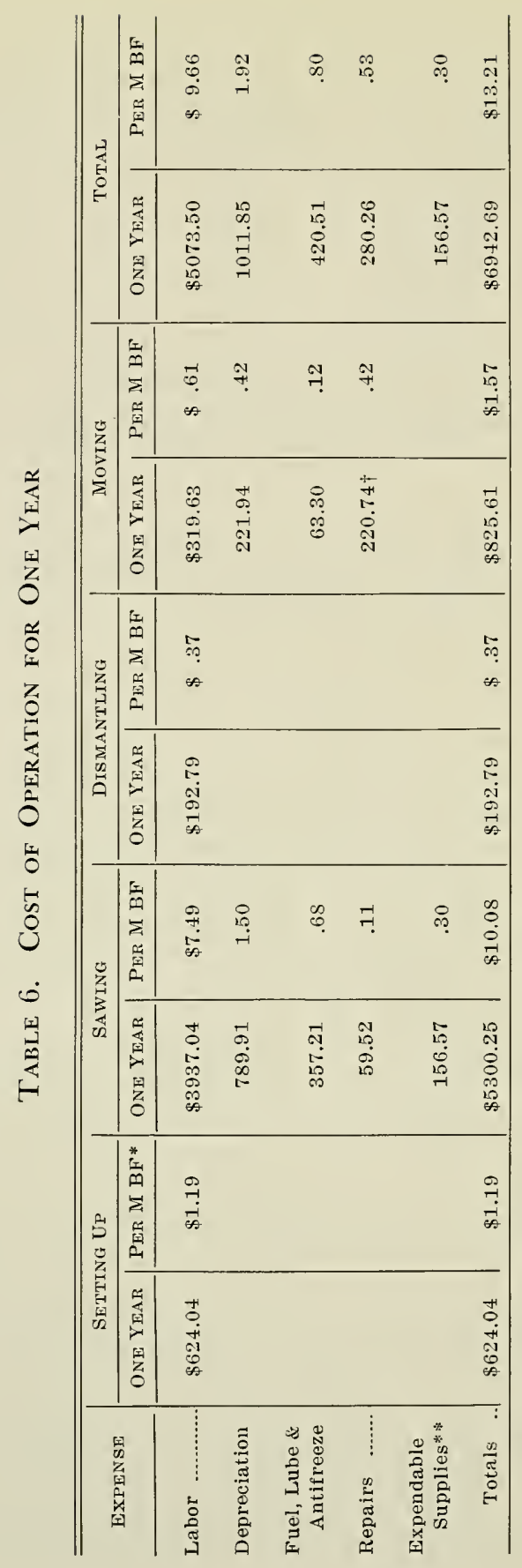

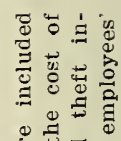
๘完

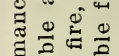
동

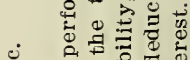
ब

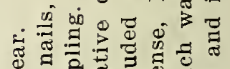
$\triangle$ a

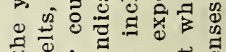
†े⿺辶寸

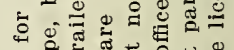
荡

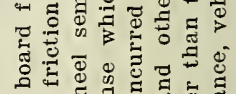
०० क. is ชै

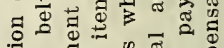
w

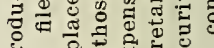

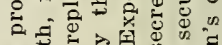
ป

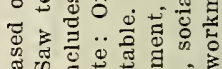
कू गु

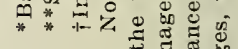

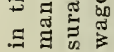




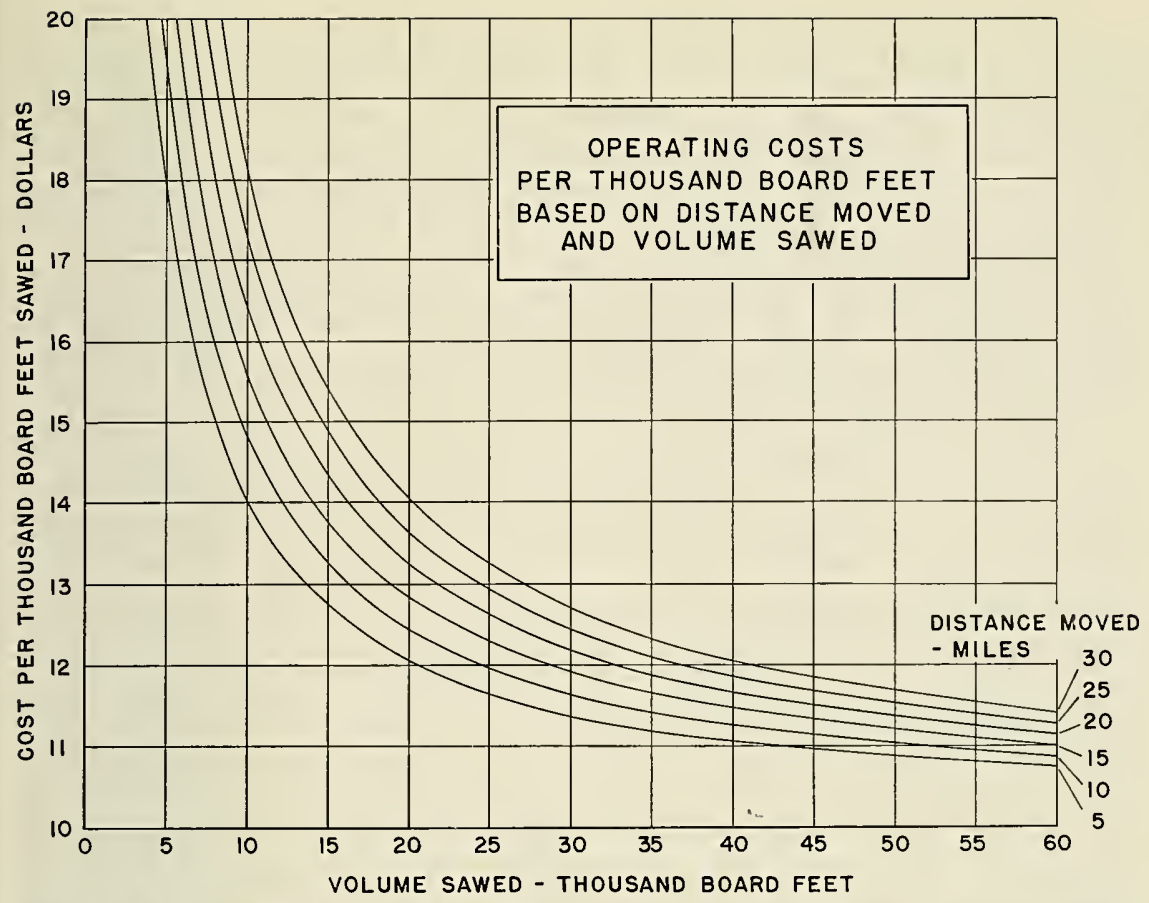

FIGURE 4. THE GRAPH is based on the average cost of sawing per thousand board feet, the average cost of moving per mile, and the average costs of setting up and dismantling per operation. Costs not included are (1) management, (2) office expense, (3) insurance, (4) social security taxes other than that deducted from employees' wages, (5) workmen's compensation taxes, (6) vehicle licenses, and (7) interest.

\section{ANALYSIS OF RESULIS}

\section{Mechanical Operation}

The mechanical operation of the unit both in sawing and moving was satisfactory. Operating efficiency could have been improved by (1) lengthening the end sections of the ways to 15 feet, giving an over-all length of 45 feet; (2) by installing an adequate landing gear for raising and lowering the front end of the trailer; and (3) by designing a power unit which would free the truck-tractor for other use while the unit was in operation.

The quality of lumber produced was excellent for a mill of its size and capacity. Stability and rigidity during operation were adequate. Large logs sometimes threw the ways out of line, but this occurred so infrequently and was so easily corrected that it did not constitute much of a problem. 
The average time required to set up the unit was almost a full 8-hour workday. Choice of the location for the set was the principal factor in the time required. Setting up on hillsides necessitated extra work in digging in for the sills on which the jacks rested. Setting up on hard soil or rocky ground required more time for digging in footers and excavating the sawdust pit.

Installation of a suitable landing gear or trailer jack for use in raising and lowering the front end of the trailer would have been the most significant mechanical improvement in reducing the time necessary for setting up and dismantling the unit.

Maneuverablity of the unit in transit was excellent. The semitrailer offered several advantages over the two- or four-wheeled trailer with pintle hitch. If a pintle hitch had been used, the over-all length of the unit in transport would have been extended six or more feet. This would have affected the turning radius of the unit and would not have offered as much control in maneuvering, particularly in backing. The advantage in use of a pintle hitch would have been that the front of the trailer would not have to be raised or lowered as far in setting up and dismantling the mill. The pintle coupling would not interfere with the use of the truck for other purposes as much as the fifth wheel because the pintle is mounted on the rearmost crossmember of the truck frame, whereas the fifth-wheel coupling is mounted above the frame over the rear axle.

A tandem-axle tractor, such as a war surplus 2-ton $6 \times 6$ truck, particularly if it had a front-mounted winch, would have had many advantages over the single-axle truck which was used. On several occasions the unit bogged down while traveling over wet fields or other soft ground. This increased moving costs.

\section{Initial Cost}

Initial cost of the unit was $\$ 9,222.66$. The cost of the mill itself was $\$ 2,549.51$, which included the standard type of portable mill, materials used in assembling the mobile unit, and labor. The remainder of the cost was for the trailer, truck-tractor, diesel engine, and accessories. By using prudent judgment in procuring the latter items, the cost of assembling a similar unit could be reduced considerably below the cost of the experimental model, with consequent savings in sawing costs.

The trailer used on the experimental model was custom-made by a commercial trailer manufacturer. An adequate trailer could be conconstructed at considerably less cost by using a heavy long-wheelbase truck frame and rear end, with air brakes added. The trailer could be assembled with or without springs, according to the desires of the builder. 
The disadvantages of springs would be that they would hold the trailer higher, complicating the problem of lowering it close to the ground in setting up for operation. On the other hand, without springs, the trailer and fifth-wheel coupling are twisted severely when the unit travels on uneven ground.

In the experimental model a new truck-tractor was used. This was not necessary, as indicated by the fact that the vehicle traveled only about a thousand miles a year. A second-hand truck, particularly a war surplus 2-ton $6 \times 6$, which could have been purchased at a fraction of the cost of a new truck, would have reduced the cost of transport considerably and would have served the purpose equally well or better.

A question that remains unanswered by this study is whether a gasoline engine would be less expensive to operate on this unit than the diesel. For equal horsepower a gasoline engine is less expensive in initial cost, smaller in size, and lighter in weight, while fuel and maintenance costs are normally higher. It is possible that the lower initial costs, even with the higher operating cost of the gasoline engine, would result in a net saving in porver expense for this unit which operated about 1,200 hours, the equivalent of 150 working days, cluring the year. The smaller size and lighter weight of the gasoline engine would be a decided advantage, especially under a modified mill plan in which the power unit was carried on the sawmill trailer, transported on a separate trailer, or removed from the tractor when the mill was in operation.

\section{Depreciation}

Although depreciation through wear and tear was not significantly greater for the mobile mill than it would be for an ordinary portable mill, depreciation expense for certain parts of the unit was high per unit of production due to high initial costs. This included the tractor and trailer, with the question unanswered regarding the power unit, as discussed in the previous section.

The total annual depreciation for the tractor and trailer was estimated to be $\$ 286.75$. On the basis of the first year of operation, this amounted to about $\$ .55$ per thousand board feet sawed. Total depreciation for the entire unit on the same basis was estimated at $\$ 1.92$. Depreciation of the tractor and trailer therefore amounted to 29 per cent of the total depreciation on a per unit of production basis. This figure could have been reduced somewhat by use of a second-hand tractor and homemade trailer. 


\section{Operating Costs}

Sawing costs were not considered to be out of line with comparable costs for an ordinary portable sawmill. It is doubtful that a significant saving in labor costs could be accomplished without an increase in the number of accessories attached to the mill. Although the spot check referred to previously indicated that as much as 30 per cent of sawing time was actually consunied in filing the saw and making adjustments to the mill, this was not lost labor time for the mill crew. While the sawyer was filing, the mill crew performed other necessary chores, such as moving lumber, slabs, and sawdust, peeling logs, refueling the diesel engine, greasing the mill, and filling the log deck.

\section{Management}

Operation of the mobile sawmill was under the supervision of a mill manager who was employed on a half-time basis. Sets were chosen and arranged for by the mill manager and a representative of the West Fork Soil Conservation District. Accurate cost figures for administration and supervision are not available. Experience points to this factor, however, as one of the most critical problems in the operation of the mobile type sawmill in sawing small sets. Demands on the manager were greatest when the workload of the mill was lightest, because of the additional work required in keeping jobs scheduled ahead of operation. 


\section{LITERATURE CITED}

1. Garver, R. D., "Portable Band Sawmills," American Lumberman, July 26, 1930.

2. _-_- "The Portable Band Sawmill," Southern Lumberman, June 15, 1946.

3. - - _- "Trailer Sawmill Goes to the Logs," Southern Lumberman, April 15, 1945.

4. ____, "Traveling Sawmill," The Timberman, July, 1945.

5. -_-_, "Wheel-Mounted Sawmill and Yarder," The Timberman, August, 1946.

6. - - - , "Wheel-Mounted Sawmill," The Timberman, November, 1946.

7. United States Census of 1945, Vol. 1, Part 15, Virginia and West Virginia. 


